\title{
幌延深地層研究センターゆめ地創館および地下研究施設を活用した リスク・コミュニケーション
}

\section{大澤英昭*1 野上利信*1 星野雅人*1 徳永博昭 $* 2$ 堀越秀彦*2}

日本原子力研究開発機構幌延深地層研究センターでは, 国民のみなさまの地層処分技術に関する研究開発および地層 処分の理解を深めることを目的に, ゆめ地創館および地下研究施設を活用してリスク・コミュニケーションを実施して きた. 本稿では，2013〜2017 年度，これらの施設の見学後に実施しているアンケート調査の結果を分析した. その結果 は, 理解度が深まると, 長期の安全性についてはより不安な要素としてクローズアップされていることを示唆している. また，地下研究施設を見学している回答者の方々が，見学していない回答者の方々と比較して，地層処分の必要性，適 切性，安全性をポジティブに評価していることなどから，本施設の見学が，地層処分の理解にとって貴重な体験になっ ていることが示唆される.

Keywords: 高レベル放射性廃棄物, 地層処分, 地下研究施設, リスク・コミュニケーション

\begin{abstract}
Japan Atomic Energy Agency has performed risk communication at Horonobe Underground Research Center, using the Public Information House and Underground Research Laboratory (URL), to promote understanding R\&D of geological disposal technology and geological disposal to public. In this paper, we carried out the analysis of questionnaire investigation performing after visiting those facilities from FY2013 to FY2017. The results show that long-term safety would gain prominent attention as agita factor by growing understanding. The results also show that visiting to those facility would become valuable experience to understand geological disposal because, for example, respondents with visiting to URL positively evaluated necessity, appropriates and safety of geological disposal, compared with those without visiting URL.

Keywords: high-level radioactive waste, geological disposal, underground research laboratory, risk communication
\end{abstract}

\section{1 はじめに}

高レベル放射性廃棄物（High-level radioactive waste；以下， HLW）の地層処分技術に関する基盤的な研究開発を担う日 本原子力研究開発機構（Japan Atomic Energy Agency; 以下, JAEA）は，1994 年 6 月に原子力委員会が策定した「原子 力の研究，開発及び利用に関する長期計画」[1]に示された 深地層の研究施設の 1 つとして, 北海道幌延町で幌延深地 層研究計画を進めている. 2015 年 5 月に閣議決定された特 定放射性廃棄物の最終処分に関する基本方針[2]では，「国 及び関係研究機関は, 最終処分の安全規制・安全評価のた めに必要な研究開発, 深地層の科学的研究等の基盤的な研 究開発及び最終処分技術の信頼性の向上に関する技術開発 等を積極的に進めていくものとする」とされており，深地 層の研究施設は, これらの研究を進めるための重要な施設 の 1 つである. そのため, 幌延深地層研究計画では, 地層 処分に関連する技術を実際の地質環境に適用し, その実用 性や信頼性を確認することを通じて, 地層処分技術の信頼 性を向上させることを大きな目的として, 2001 年 3 月より, 段階的に（第 1 段階; 地上からの調查研究, 第 2 段階; 坑 道掘削（地下施設建設）時の調查研究，第 3 段階 ; 地下施 設での調査研究), 研究開発を進めてきた. 第 1 段階の調査 研究は, 2006 年 3 月末までの約 5 年間にわたって実施し,

Risk Communication at Horonobe Underground Research Center, Using the Public Information House and Underground Research Laboratory - by Hideaki OSAWA (ohsawa.hideaki@jaea.go.jp), Toshinobu NOGAMI, Masato HOSHINO, Hiroaki TOKUNAGA, Hidehiko HORIKOSHI

*1 国立研究開発法人日本原子力研究開発機構核燃料バックエンド研 究開発部門幌延深地層研究センター

Horonobe Underground Research Center, Sector of Nuclear Fuel, Decommissioning and Waste Management Technology Development, Japan Atomic Energy Agency

干098-3224 北海道天塩郡幌延町北進 432-2

*2 株式会社ペスコ

PESCO Co., Ltd

干105-0021 東京都港区東新橋 2-5-12 第一粕谷ビル 7F

(Received 15 March 2019; accepted 17 May 2019)
研究所設置地区およびその周辺において，空中物理探査お よび地上からの様々な調査研究を展開するとともに，そこ で得られた地質環境情報，あるいは岩石や地下水の試料な どを利用した調査研究を進めた[3]. 2005 年 11 月に開始し た地下施設工事では, 2006 年 9 月に東立坑の掘削を開始し, 2011 年 2 月には 3 本目の立坑となる西立坑の掘削を開始し たここの間, 深度 $140 \mathrm{~m}$ および深度 $250 \mathrm{~m}$ の調査坑道を整備 するとともに, 深度 $350 \mathrm{~m}$ の調查坑道は 2014 年 1 月に掘 削が完了している (Fig.1)。これら地下施設の建設と並行 して, 2005 年から第 2 段階の坑道掘削（地下施設建設）時 の調査研究を進めてきた[4]. 2010 年からは第 3 段階の地下 施設での調査研究を進め, 現在は, 「実際の地質環境におけ る人工バリアの適用性確認」,「処分概念オプションの実証」,

「地款変動に対する堆積岩の緩衝能力の検証」の 3 つの研 究課題に取り組んでいる[5].

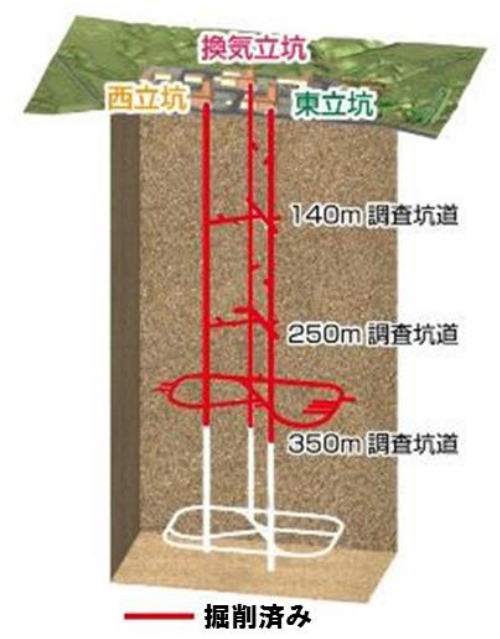

Fig.1 Layout of the Horonobe Underground Research Laboratory (The red regions indicate excavations completed by June 2014) 
なお，幌延深地層研究計画は，2000 年 11 月に国（科学 技術庁, 現 文部科学省）の立ち会いの下に，幌延町，北海 道およびサイクル機構（現 JAEA）間で「幌延町における 深地層の研究に関する協定」を締結し，2001 年 3 月に第 1 段階の調查研究を開始した. 協定には,「研究実施区域に放 射性廃棄物を持ち込むことや使用することはしない」，「深 地層の研究所を放射性廃棄物の最終処分を行う実施主体一 譲渡，貸与しない」，「研究終了後は地上の研究施設を閉鎖 し，地下施設を埋め戻す」，「研究実施区域を将来とも放射 性廃棄物の最終処分場とせず, 幌延町に放射性廃棄物の中 間貯蔵施設を将来とも設置しない」ことなどが定められて いる.

一方, 深地層の研究施設は,「学術研究の場であるととも に, 国民の地層処分に関する研究開発の理解を深める場と しての意義を有し，その計画は，処分施設の計画と明確に 区分して進めることが必要」[6]とされている．そのため, 深地層の研究施設においては，国内外の研究機関や専門家 との研究協力を積極的に進め，また，広く学術的な研究の 場としての活用を図るとともに，国民のみなさまが地下深 部の環境を実際に体験・学習し, 研究者との対話を通じて, 地層処分やその研究開発に対する理解を深める場としても 整備していくことになっている。このため, 幌延深地層研 究センターでは, HLW 地層処分技術に関する研究内容を紹 介したゆめ地創館と, 深地層の研究施設の 1 つである幌延 深地層研究所（以下，地下研究施設）を活用して，地層処 分技術の研究開発および地層処分に関するリスク・コミュ ニケーションを実施している．ゆめ地創館は，毎週月曜日 および年末年始を除き，自由に見学可能なように公開して いる．また，地下研究施設の見学については，4～10 月は 火・木曜日の 2 日間， 11〜3 月は木曜日に，また，4〜10 月の第 4 日曜日に, 事前予約制で見学を受け付けている[7]. なお，事前予約なしで来館された見学者は，研究を紹介し たゆめ地創館[8]（HLW の地層処分技術をパネルや実規模 の模型，ビデオなどで紹介した施設）と地層処分実規模試 験施設（人工バリアの実規模模型や緩衝材定置試験装置, 緩衝材を用いた簡易実験など）[9]を自由に見学されている。 また, 地下研究施設の見学を事前予約されてきた見学者は, 地下研究施設の他, ゆめ地創館と地層処分実規模試験施設 を案内され，見学されている.

本稿では, 幌延深地層研究センターゆめ地創館および地 下研究施設を活用したリスク・コミュニケーションにおい て，施設見学後に実施したアンケート調查（2013～2017年 度の 5 年間) の結果[10-13]を示す.なお, ゆめ地創館は 2007 年 6 月に開館, 地下研究施設の見学については, 2007 年に 建設工事現場の地上見学を開始して以降，建設の進捗に伴 い段階的に見学箇所を拡大しつつ, 2014 年から深度 $350 \mathrm{~m}$ の調査坑道の見学を開始しているが, 本アンケート調查は, 国や地層処分事業の状況を踏まえ，地層処分に対する認 識・意識を問う設問をアンケートに加えた内容で, 2013 年 から実施している．そのため，本稿では，2013 年からのア ンケート調査を対象としている.

\section{2 調查方法}

幌延深地層研究センターでは，見学者を対象に，ゆめ地 創館, 地下研究施設の見学後の感想 (理解度), 地層処分に 関する認識，地層処分の安全性に対する不安，地層処分を 行う上での技術的な課題などについて，アンケート調査を 実施している.

回答者の属性のうち, 年齢は「10 歳代以下」, 「20歳代」, $\lceil 30$ 歳代」, 「40 歳代」, 「50 歳代」,「60 歳代以上」から, 居住地は「幌延町」, 「北海道内」, 「北海道外」から選択,

「当該施設をどのように知ったか」については,「インター ネット」,「パンフレット」,「広報誌」,「知人の紹介」,「通 りすがり」，「その他」から選択していただき，「その他」に ついては内容を自由記載していただいた。 そのため,「当該 施設をどのように知ったか」については，一部の回答者が 複数回答している.ゆめ地創館, 地下研究施設の見学後の 感想 (理解度)については, 「幌延深地層研究センターで行 っている調査・研究内容」,「地層処分」,「高レベル放射性 廃棄物」，「実物大の人工バリア」，「実物大の人工バリアを 使った試験」について，「良くわかった」，「大体わかった」，

「あまりわからなかった」，「全くわからなかった」で測定 した.

また，地層処分に関する認識については，「日本では，高 レベル放射性廃棄物を国内の地層中に処分（地層処分）す る計画があることをご存じでしたか?」(地層処分計画の認 知度）に対し「知っていた」，「何となく（少し）知ってい た」,「知らなかった」で，「高レベル放射性廃棄物の処分の 必要性についてどう感じましたか?」(処分の必要性)に対 し「必要」,「多少, 必要」,「あまり必要ではない」,「不要」, 「わからない」で，「高レベル放射性廃棄物の処分方法とし て, 地層処分が適していると思いますか?」（地層処分の適 切さ）に対し「適している」，「適していない」，「わからな い」で，「地層処分の安全性についてどう感じましたか?」 （地層処分の安全性）に対し「安全」,「多少, 安全」,「多 少, 不安」,「不安」,「わからない」で測定した.

また, 地層処分の安全性に関し「多少, 不安」,「不安」, あるいは「わからない」と回答した人を対象に,「長期間 (数 万年）の管理」,「長期間（数万年）減らない放射能」,「放 射能が外部に漏れてくる可能性」,「日本には適地がない」,

「想定外のことが起こる可能性」,「わからない,,「その他 (自由記載)」から, 地層処分の安全性について何が不安か を，複数選択可能という条件で測定した。

さらに,「地下水の動き」, 「地殼変動（地震, 火山等）」, 「数万年先の予測」, 「ガラス固化体の健全性」,「わからな い,，「その他 (自由記載)」から，地層処分を行う上での技 術的な課題に関し, 複数選択可能という条件で測定した.

そのうえで，その他わからなかった点，疑問点，知りた いこと, 不安な点, ご意見を自由記載していただいた[13].

なお, 2013〜2014 年度のアンケート調査のデータセット は，冬期の見学者が激減することもあり，基本的に 4 月〜 11 月までとされている（初期の 2013 および 2014 年度は試 行段階ということもあり, データセットが整備されたのは 11 月 20 日までとなっている. そのため, それ以降 11 月末 
日までの 18 名（2013 年度），57 名（2014 年度）の回答者 の情報は含まれていない)。2017 年度は，科学的特性マッ プの公表が 7 月に行われ，冬期の見学者がそれまでより増 加したことから，1月 21 日までの回答者がデータセットに 含められている (12月以降の回答者 158 名が含まれている) 分析に用いたデータセットの集計期間に上記のような差が あり，定量的な比較・評価を行うことは難しいため，本稿 では，定性的に 5 年間の大まかな変化や認められた特徵的 な傾向を取り扱うこととした.

\section{3 結果と考察}

\section{1 回答者の属性}

2013～2017 年度の 5 年間の回答者の性別の傾向は, 男性 が約 $60 \%$ と女性（約 $30 \%$ ）より多く，5 年間でその傾向に 大きな変化はない，年齢層も，多い順に 60 歳代以上，50 歳代，40 歳代，30 歳代，20 歳代の傾向を示しており，5 年間でその傾向に大きな変化はない（Table 1)。回答者の 居住地は，多い順に北海道内，北海道外，幌延町で 5 年間 変化はないが，2016 年度以降，北海道外の割合が増加（依 然として北海道内の割合が大きいものの，北海道外との差 は小さいものとなっている）している（Fig.2）。当施設を どのように知ったかについては，「通りすがり」が最も多く

(約 30\%), 以下順に，年によって若干の変動はあるもの の,「その他」,「知人の紹介」,「パンフレット」,「インター ネット」，「広報誌」となっている（Table 1)。この内，割 合の大きな「その他」という回答をしたものに関し，より 詳しく内訳をみると，2016 年度以降，全回答者に対する割 合としては小さいものの，「業務・学業・関係者」の回答者 が増加している（Fig.3, Table 2)．2016，2017 年度で北海道 外の居住者で大きな割合 (2016 年度 : $25.4 \%, 2017$ 年度 : $30.6 \%$ ）をしめる「その他」という回答をした人の内訳を

Table 1 Attribute of respondents

\begin{tabular}{|c|c|c|c|c|c|c|}
\hline \multicolumn{2}{|c|}{-2} & 2013 & 2014 & 2015 & 2016 & 2017 \\
\hline \multicolumn{2}{|c|}{ 見学者数 (人) } & 6,806 & 7,874 & 6,880 & 6,937 & 7,668 \\
\hline \multicolumn{2}{|c|}{ 回答者数 (人) } & 2,566 & 2,457 & 2,674 & 2,795 & 3,842 \\
\hline \multirow{3}{*}{ 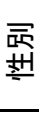 } & 男性 & 62.4 & 61.7 & 62.5 & 64.6 & 64.5 \\
\hline & 女性 & 32.6 & 33.6 & 32.8 & 30.8 & 31.2 \\
\hline & 無回答 & 5.0 & 4.7 & 4.7 & 4.6 & 4.2 \\
\hline \multirow{7}{*}{ 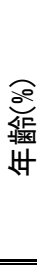 } & 10歳代以下 & 8.8 & 8.5 & 8.2 & 5.5 & 4.1 \\
\hline & 20歳代 & 10.0 & 8.7 & 9.7 & 9.9 & 9.9 \\
\hline & 30歳代 & 14.1 & 14.8 & 12.5 & 13.7 & 10.9 \\
\hline & 40歳代 & 18.0 & 18.4 & 19.2 & 18.6 & 17.7 \\
\hline & 50歳代 & 17.9 & 18.8 & 19.7 & 22.1 & 20.4 \\
\hline & 60歳代以上 & 29.9 & 29.5 & 29.5 & 29 & 34.6 \\
\hline & 無回答 & 1.3 & 1.3 & 1.2 & 1.0 & 2.6 \\
\hline \multirow{4}{*}{ 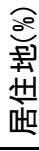 } & 幌延町 & 4.4 & 4.4 & 4.6 & 3.5 & 4.3 \\
\hline & 北海道内 & 55.1 & 57.8 & 54.5 & 43.9 & 45.3 \\
\hline & 北海道外 & 28.2 & 25.8 & 28.1 & 39.5 & 39.7 \\
\hline & 無回答 & 12.3 & 12.0 & 17.4 & 13.2 & 10.7 \\
\hline \multirow{7}{*}{ 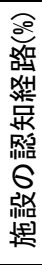 } & インターネット & 7.8 & 9.6 & 8.6 & 7.9 & 7.2 \\
\hline & パンフレット & 11.3 & 14.6 & 11.9 & 10.5 & 7.8 \\
\hline & 広報誌 & 6.3 & 8.8 & 7.4 & 5.2 & 5.1 \\
\hline & 知人の紹介 & 20.8 & 17.6 & 18.2 & 17.3 & 19.1 \\
\hline & 通りすがり & 31.2 & 31.8 & 38.4 & 33.3 & 28.6 \\
\hline & その他 & 21.9 & 19.2 & 17.1 & 20.9 & 25.7 \\
\hline & 無回答 & 2.5 & 2.6 & 2.8 & 5.0 & 6.5 \\
\hline
\end{tabular}

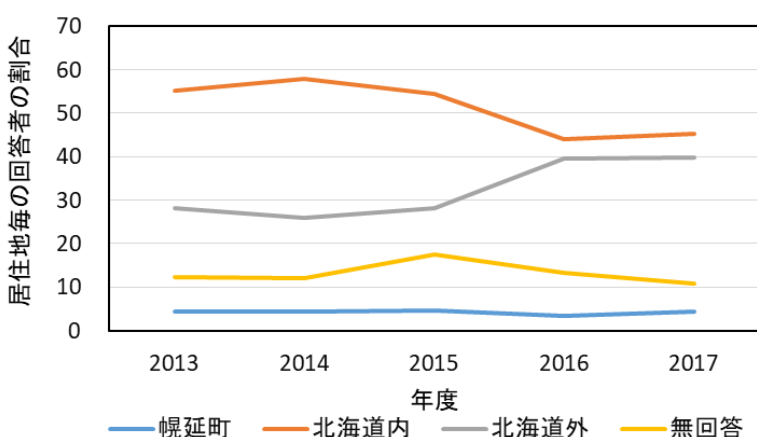

Fig.2 Change in ratio of respondents by the residence

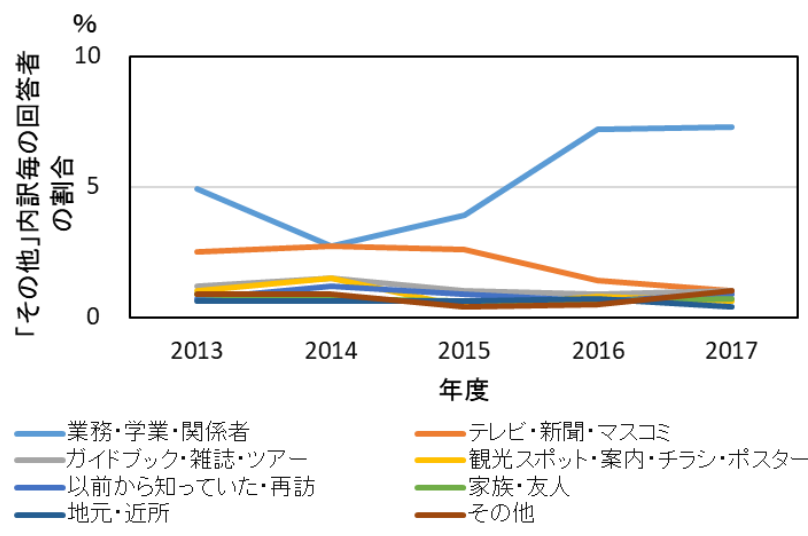

Fig.3 Change in ratio of information source how respondents, answering 'others', knew URL at Horonobe

Table 2 Ratio of information source how respondents, answering 'others', knew URL at Horonobe

\begin{tabular}{|c|c|c|c|c|c|c|c|c|c|c|}
\hline \multirow{2}{*}{ その他の内訳 } & \multicolumn{2}{|c|}{ 2013年度 } & \multicolumn{2}{|c|}{ 2014年度 } & \multicolumn{2}{|c|}{ 2015年度 } & \multicolumn{2}{|c|}{ 2016年度 } & \multicolumn{2}{|c|}{ 2017年度 } \\
\hline & 回答者数 & 割合( $(x)$ & 回答者数 & 割合(\$) & 回答者教 & 割合( $(x)$ & 回答者数 & 割合(\%) & 回答者数 & 割合( $($ ) \\
\hline 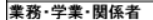 & 127 & 4.9 & 67 & 2.7 & 104 & 3.9 & 201 & 7.2 & 281 & 7.3 \\
\hline 宗レビ·新聞·マスコミ & 63 & 2.5 & 66 & 2.7 & 69 & 2.6 & 39 & 1.4 & 38 & 1.0 \\
\hline $\begin{array}{l}\text { ガイドブック・錐誌・ } \\
\text { ッアー }\end{array}$ & 30 & 1.2 & 37 & 1.5 & 27 & 1.0 & 25 & 0.9 & 38 & 1.0 \\
\hline 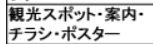 & 26 & 1.0 & 36 & 1.5 & 11 & 0.4 & 21 & 0.8 & 23 & 0.6 \\
\hline $\begin{array}{l}\text { 刿前から知っていだ } \\
\text { 再訪 }\end{array}$ & 17 & 0.7 & 30 & 1.2 & 23 & 0.9 & 16 & 0.6 & 34 & 0.9 \\
\hline 家筷·友人 & 16 & 0.6 & 15 & 0.6 & 17 & 0.6 & 16 & 0.6 & 25 & 0.7 \\
\hline 地元·近所 & 24 & 0.9 & 17 & 0.7 & 15 & 0.6 & 20 & 0.7 & 16 & 0.4 \\
\hline その他 & 24 & 0.9 & 21 & 0.9 & 11 & 0.4 & 13 & 0.5 & 37 & 1.0 \\
\hline 無回答 & 236 & 9.2 & 183 & 7.4 & 179 & 6.7 & 233 & 8.3 & 497 & 12.9 \\
\hline 合計 & 563 & 21.9 & 472 & 19.2 & 456 & 17.1 & 584 & 20.9 & 989 & 25.7 \\
\hline
\end{tabular}

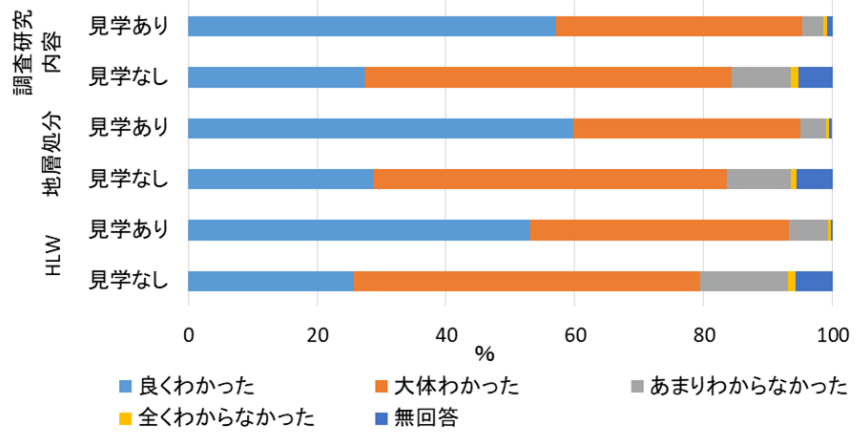

Fig.4 Understanding-level of geological disposal by the respondent with or without visiting to URL in 2017

より詳しくみると， 2014 年度を除き，北海道外は「業務・ 学業・関係者」の回答者の割合が北海道内および幌延町と 比較し高い傾向を示し,かつ 2016 年度以降その割合は増加 
している（2015 年度 : $6.0 \% ， 2016$ 年度 : $11.6 \% ， 2017$ 年 度 : $12.0 \%)$.

\subsection{HLW 地層処分に関する感想（理解度）}

見学後の HLW 地層処分に関する感想（理解度）につい ては，「幌延深地層研究センターで行っている調査・研究内 容」，「地層処分」，「高レベル放射性廃棄物」，「実物大の人 工バリア」，「実物大の人工バリアを使った試験」ともに， 各年度も約 8 割の回答者が「良くわかった」あるいは「大 体わかった」と回答している[10-13].

また，いずれの項目も，地下研究施設の見学を行った回 答者（地下研究施設とあわせて，ゆめ地創館と地層処分実 規模試験施設を見学）の方が，地下研究施設の見学を行っ ていない回答者（ゆめ地創館と地層処分実規模試験施設を 自由に見学) と比較し，その理解度が高くなっている (2017 年度の例を Fig.4 に示す)。

\section{3 HLW 地層処分に関する認識}

「地層処分計画の認知度」に関しては, 約 $80 \%$ を超える 回答者が「知っていた」あるいは「何となく知っていた」 と回答し，「知らなかった」と回答したのは約 $12 \%$ ありり， 5 年間その傾向に大きな変化はない. また,「処分の必要性」 についても, 約 $80 \%$ を超える回答者が「必要」あるいは「多 少，必要」と回答し。「あまり必要ではない」あるいは「不 要」と回答したのは $5 \%$ 程度であり, 5 年間その傾向に大き な変化はない（Table 3)

一方で，「地層処分の適切さ」については，2016 年度以 降，「適している」との回答者が若干増加（Fig.5）, また, 「地層処分の安全性」についても，2016 年度以降，「安全」 との回答が増加し，「不安」との回答者は減少傾向を示して いる（Fig. 6)。「地層処分の適切さ」については，幌延町 (N

Table 3 Recognition of geological disposal

\begin{tabular}{|c|c|c|c|c|c|c|}
\hline & & 2013 & 2014 & 2015 & 2016 & 2017 \\
\hline & 知っていた & 55.6 & 57.1 & 56.1 & 56.0 & 54.1 \\
\hline $\begin{array}{l}\text { 地層処分 } \\
\text { 計画の認 }\end{array}$ & $\begin{array}{l}\text { 何となく(少 } \\
\text { し)知っていた }\end{array}$ & 29.9 & 28.6 & 30.1 & 29.6 & 26.6 \\
\hline 知度 (\%) & 知らなかった & 12.6 & 12.5 & 12.1 & 12.1 & 11.5 \\
\hline & \begin{tabular}{|l|} 
無回答 \\
\end{tabular} & 1.9 & 1.8 & 1.8 & 2.3 & 7.8 \\
\hline & 必要 & 64.3 & 64.3 & 65.1 & 69.1 & 65.4 \\
\hline & 多少, 必要 & 16.8 & 17.7 & 18.3 & 16.0 & 15.7 \\
\hline & わからない & 9.9 & 10.2 & 8.8 & 7.5 & 6.2 \\
\hline 要性 (\%) & $\begin{array}{l}\text { あまり必要で } \\
\text { はない }\end{array}$ & 2.8 & 2.4 & 2.5 & 2.0 & 2.1 \\
\hline & 不要 & 2.9 & 2.4 & 2.8 & 2.4 & 2.0 \\
\hline & \begin{tabular}{|l} 
無回答 \\
\end{tabular} & 3.3 & 3.0 & 2.5 & 3.0 & 8.6 \\
\hline & 適している & $4 \quad 41.6$ & 38.5 & $\begin{array}{l}40.5 \\
\end{array}$ & 4 & 年46.7 \\
\hline $\begin{array}{l}\text { 地層処分 } \\
\text { 谪切さ }\end{array}$ & わからない & 47.2 & 51.2 & 48.8 & 48.3 & 38.3 \\
\hline 适均C & 適していない & 8.2 & 7.6 & 8.2 & 6.8 & 6.2 \\
\hline & 無回答 & 3.0 & 2.7 & 2.5 & 3.1 & 8.8 \\
\hline & 安全 & 18.6 & 17.0 & 17.4 & 24.0 & 24.0 \\
\hline & 多少, 安全 & 22.4 & 21.4 & 23.2 & 24.5 & 21.9 \\
\hline It & わからない & 12.8 & 13.6 & 11.2 & 11.2 & 10.2 \\
\hline 女全" & 多少, 不安 & 26.7 & 28.3 & 28.0 & 22.9 & 22.2 \\
\hline & 不安 & 16.8 & 17.4 & 17.9 & 14.0 & 13.0 \\
\hline & \begin{tabular}{|l} 
無回答 \\
\end{tabular} & 2.7 & 2.3 & 2.3 & 3.3 & 8.7 \\
\hline
\end{tabular}

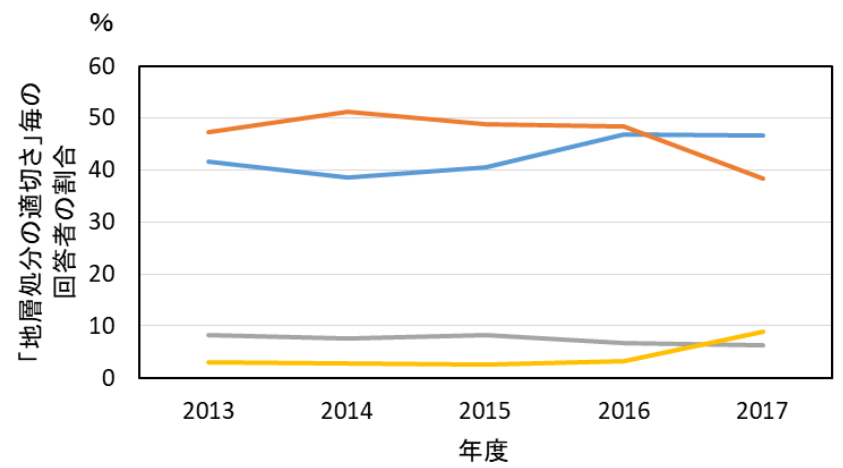

一適している 一わからない 一適していない 一無回答

Fig.5 Change in ratio of respondents by recognition on appropriateness of geological disposal

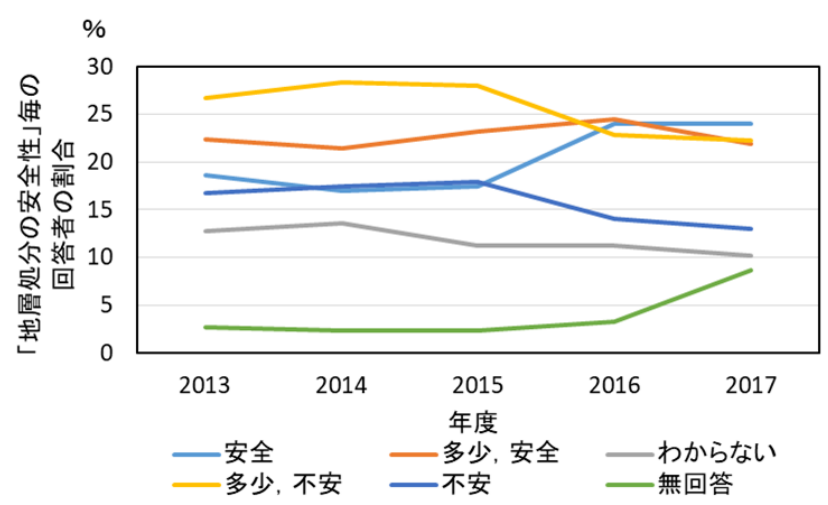

Fig.6 Change in ratio of respondents by recognition on safety of geological disposal

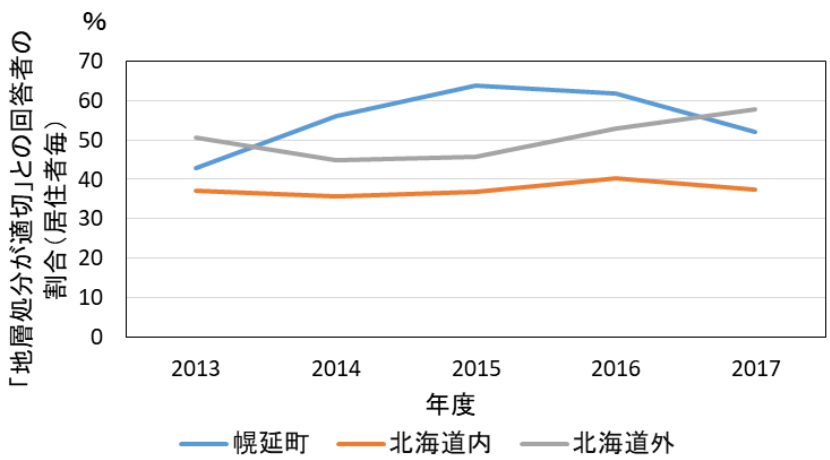

Fig.7 Change in ratio of respondents answering appropriate in terms of geological disposal by residence

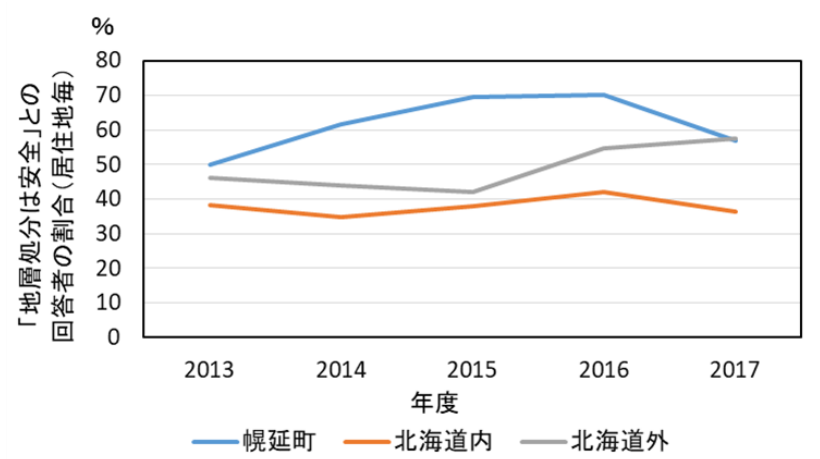

Fig.8 Change in ratio of respondents answering safe in terms of geological disposal by the residence 
(2016 年度から順に) $=112,109,124,97,167$ 名), 北海道 内 $(\mathrm{N}=1,415,1,420,1,458,1,226,1,739$ 名 $)$, 北海道外 $(\mathrm{N}=723$, 634，751，1,103，1,524 名）の居住地別で，各年度の「適 している」の割合をみると, 北海道外では 2016 年度以降に 増加している (Fig.7)。「地層処分の安全性」については, 幌延町，北海道内，北海道外の居住地別で，各年度の「安 全」および「多少，安全」と，「不安」および「多少，不安」 の割合の変化をみると，北海道外では「安全」および「多 少, 安全」が 2016 年度以降に増加 (Fig.8), 「不安」およ び「多少，不安」が減少傾向を示している（Fig.9）。

また，地下研究施設の見学の有無で「地層処分計画の認 知度」,「処分の必要性」,「地層処分の適切さ」,「地層処分 の安全性」を比較すると, いずれも地下研究施設の見学を 行った回答者の方がポジティブな回答をしている．地層処 分計画の認知については，「知っていた」および「何となく

（少し）知っていた」が，地下研究施設の見学ありの場合 は 2014 年度から順に 86.6，90.9，93.0，85.9\%，見学なし の場合は，85.5，85.9，83.0，77.8\%を示す．処分の必要性 については，「必要」および「多少，必要」が，見学ありの 場合は 89.0，92.8，96.9，88.1\%，見学なしの場合は，80.9， 82.3，81.1，77.0\%を示す. 地層処分の適切さについては,

「適している」が，見学ありの場合，45.8, 62.6, 75.9, 66.1\%， 見学なしの場合は，37.3，37.8，36.8，35.3\%を示す．地層 処分の安全性については,「安全」および「多少, 安全」が, 見学ありの場合は，55.4，69.1，75.1，63.6\%，見学なしの 場合は，35.6，37.1，38.5，35.4\%を示す.

\subsection{HLW 地層処分の安全性に対する不安内容と技術的課 題}

「地層処分の安全性に対する不安内容」については, 2016 年度から, 若干の変動はあるものの 5 年間大きな変化はな く, 不安な内容から順に, おおむね, 「想定外のことが起こ る可能性」，「長期間（数万年）の管理」，「放射能が外部に 漏れてくる可能性」,「長期間（数万年）減らない放射能」,

「日本には適地がない, となっている (Fig.10)。また，「地 層処分の技術的課題」についても，若干の変動はあるもの の 5 年間大きな変化はなく, 技術的課題だと思う順に,「地 殼変動 (地震, 火山等) 」, 「数万年先の予測」,「地下水の動 き」,「ガラス固化体の健全性」, となっている (Fig.11)。「地 殼変動 (地震, 火山等)」は最も高い技術的課題としてあげ られているが，2016 年度以降，各年度の割合は減少傾向に ある。これを居住地別にみると，2016 年度に幌延町で大き な割合を占めているものの, 北海道内, 北海道外ともに, 「地款変動（地震，火山等）」を技術的課題としてあげる割 合は減少傾向を示している (Fig.12).

「地層処分の安全性」に関し「不安」，「多少，不安」，あ るいは「わからない」と回答した人を対象に，見学後の感 想（理解度）ごとの「地層処分の安全性についての不安内 容」を，2017 年度を例に示すと，「長期間（数万年）の管 理」および「想定外のことが起こる可能性」に関しては, 理解度が高い（「良くわかった」，「大体わかった」）回答者 は，理解度の低い(「あまりわからなかった」,「全くわから なかった」）回答者よりも高い傾向を示している（Fig.13）.

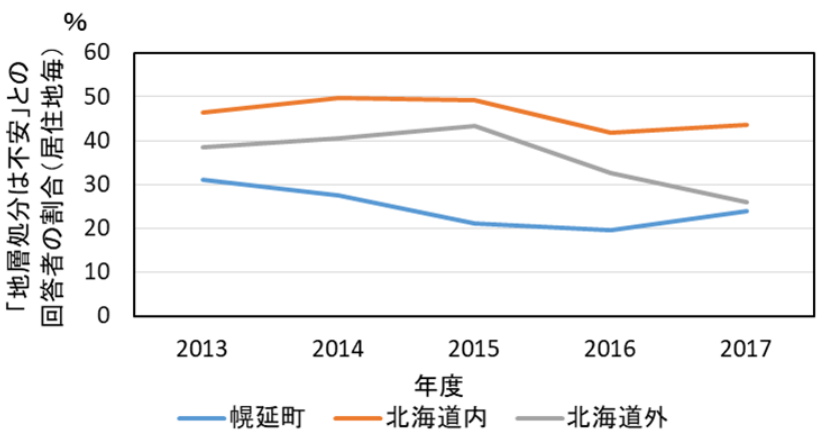

Fig.9 Change in ratio of respondents answering anxious in terms of geological disposal by the residence

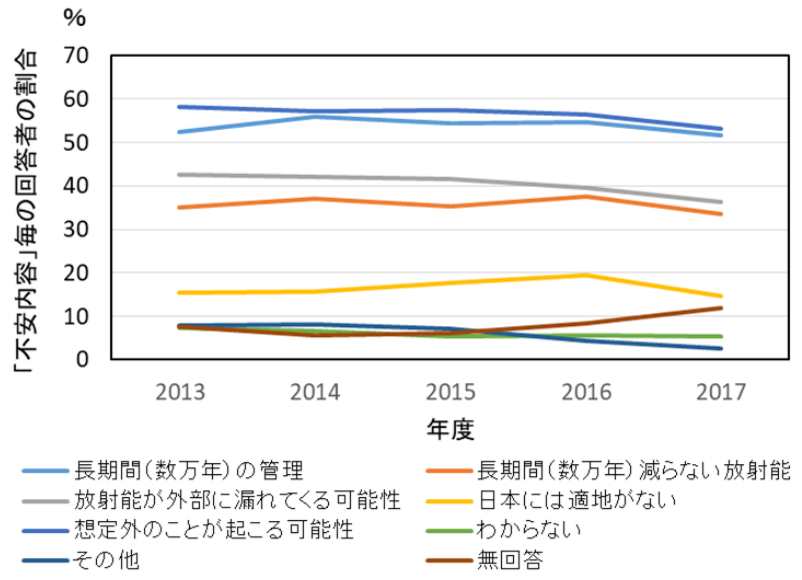

Fig.10 Change in ratio of respondents by anxious contents

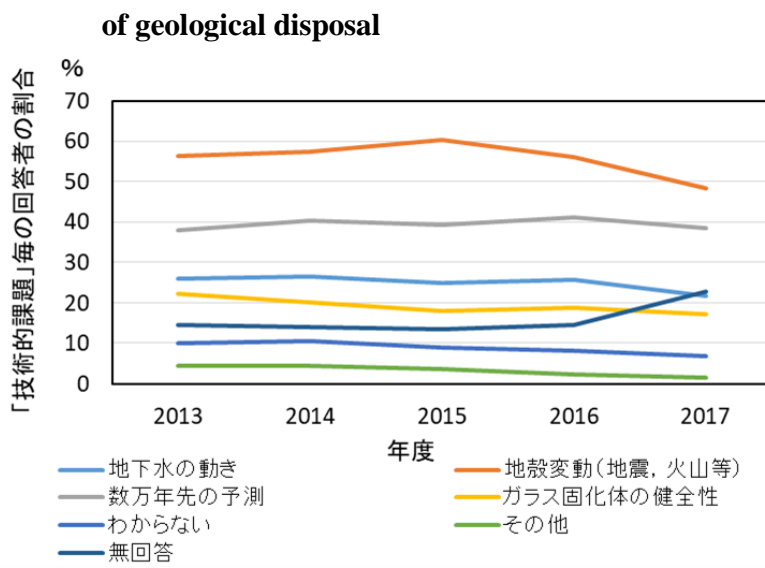

Fig.11 Change in ratio of respondents by technical issues of geological disposal

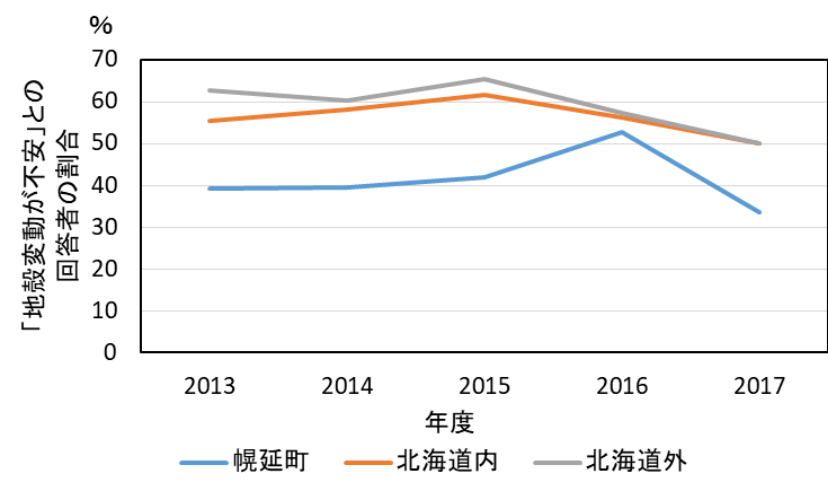

Fig.12 Change in ratio of respondents concerning crustal movement as technical issue by the residence 
四良くわかった、大体わかった、あまりわからなかった、全くわからなかった

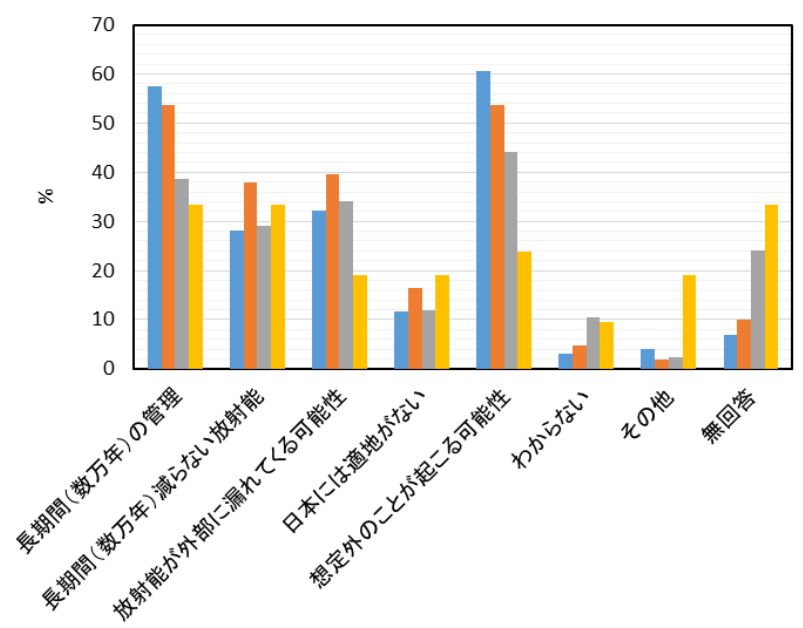

Fig.13 Anxious contents by understanding-level of geological disposal in 2017

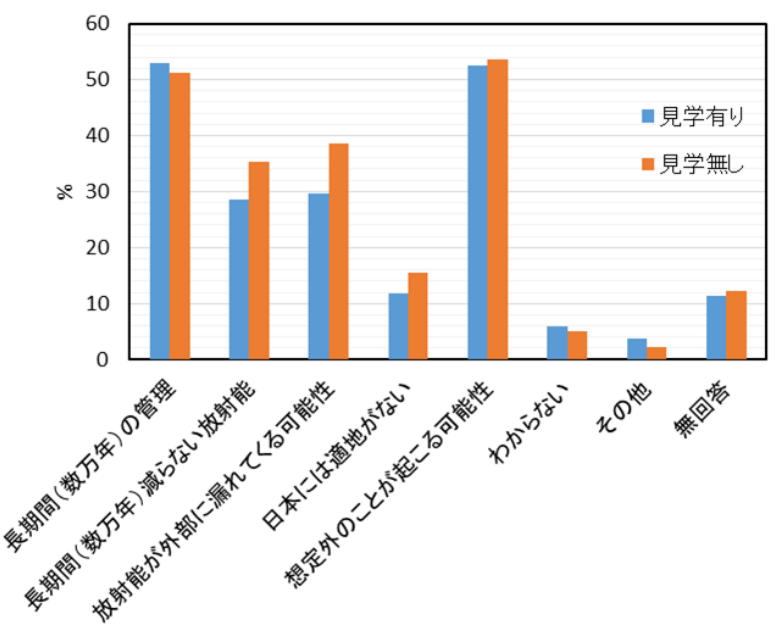

Fig.14 Anxious contents by the respondent with or without visiting to underground facility in $\mathbf{2 0 1 7}$

この傾向は，その他の年度でもおおむね同様の結果となっ ている[10-13].

また，「地層処分の安全性」に関し「不安」,「多少, 不安」, あるいは「わからない」と回答した人を対象に，地下研究 施設の見学の有無ごとの「地層処分の安全性についての不 安内容」を，2017 年度を例に分析すると，「長期間（数万 年) の管理」および「想定外のことが起こる可能性」に関 しては，地下研究施設の見学の有無に関係なく，高い傾向 を示している (Fig.14)。その他の項目は，おおむね地下研 究施設の見学していない回答者の方が高い傾向を示す。こ の傾向は，その他の年度でもおおむね同様の結果となって いる[10-13].

\section{5 意見の自由記載}

アンケート調査で自由記載していただいている「その他, わからなかった点，疑問点，知りたいこと，不安な点，ご 意見」を，テキストマイニングにより文章を単語や文節に 分割し，それらの出現頻度を集計，分析した。テキストマ
イニングは，KH coder[14]を用いて実施した．集計に当た っては，感性表現（文章に含まれる「良い」「悪い」や「要 望」「提案・忠告」等の感情的要素）と概念（何について言 及しているか) について着目した，なお，多くの回答には 複数の感情的要素と主題が含まれているため，単純な分類 はできない，また，集計対象は記載のあった回答者に限ら れるため厳密な定量化はできないため，言及されている内 容と感情の大まかな傾向を確認することを目的とした．感 性表現の抽出・分類には Institute of Language Understanding より許諾を得て, 株式会社 NTT データが OEM 提供を行っ ているエモーションアナライザライブラリを使用した.

感性表現のうち，一般的にポジティブな感情 (「よい」「… しやすい」「安心」等）を示す表現を含むものと，ネガティ ブな感情（「悪い」「…にくい」「不安」等）を含むものの 頻度を, 2016 および 2017 年度を例として Fig.15(a)に示す. 年度によってその頻度は変動するものの, 自由記載にはネ ガティブな表現より，ポジティブな表現が多い。また，「要 望」(「…してほしい」「して下さい」等)，「提案・忠告」(「… すべき」等)，「疑問」(「…゙すか」等)，「問い合わせ」(「知 りたい」「どうなのか」等)，「驚き」(「すごい」「びっくり」 等)，「激励」(「頑張れ」等）を含むものの割合を検討する と, 年度によってその割合は変動するものの, 順に, 要望, 提案・忠告，疑問あるいは激励，の順にその割合が大きい

(Fig.15(b)に 2016 および 2017 年度の例を示す).

出現する語彙を類似する概念ごとに集約すると（以下， 出現語彙),「わかる・知る・理解」,「研究開発・調査」,「説 明・案内・展示」などが多いことを示している（Fig.15(c)） に 2016 および 2017 年度の例を示す). 地層処分の安全性別 にみると，地層処分について「不安」と回答した見学者に ついては，地層処分に直接関連するもの以外に，「原子力・ 原発・核」,「お金・コスト」,「エネルギー・電力」の出現 も高いことを示している（Fig.16(a)）に2017 年度の例を示 す).

また，直近の 2017 年度を例に，ネガティブ表現を含む記 述とポジティブ表現を含む記述の中に出てくる出現語彙を 集計・分析すると, 「説明・案内・展示」,「わかる・知る・ 理解」はポジティブ表現を含む記述の中に特徵的であり,

「原子力・原発・核」,「将来・今後・未来」はネガティブ 表現を含む記述の中に特徵的である（Fig.17）.

感性表現別に出現語彙との関連性の分析を行うと,「地下 坑道」と「予測・予想・想定・想像」は「驚き」，「原子力・ 原発・核」は「提案・忠告」の言説の中で記述されている のが特徵的である（Fig.16(b)）。

さらに，感性表現と出現語彙との関連を検討するためにコ レスポンデンス分析[15]を行うと，「ポジティブ」の近くに は「説明・案内・展示」, 「施設・地創館・深地層研」,「わ かる・知る・理解」等が布置され，施設や地下・坑道での 説明・案内・展示が肯定的に評価されたことがうかがえる.

「提案・忠告」,「要望」,「ネガティブ」の近くには，「原子 力・原発・核」, 「廃棄物・HLW」等が布置され, 原子力に 対する疑問の存在がうかがえる.また，「地下坑道」は「ポ ジティブ」と「驚き」の中間方向にあり，地下坑道につい て，その存在についてポジティブに驚きを表現しているの 


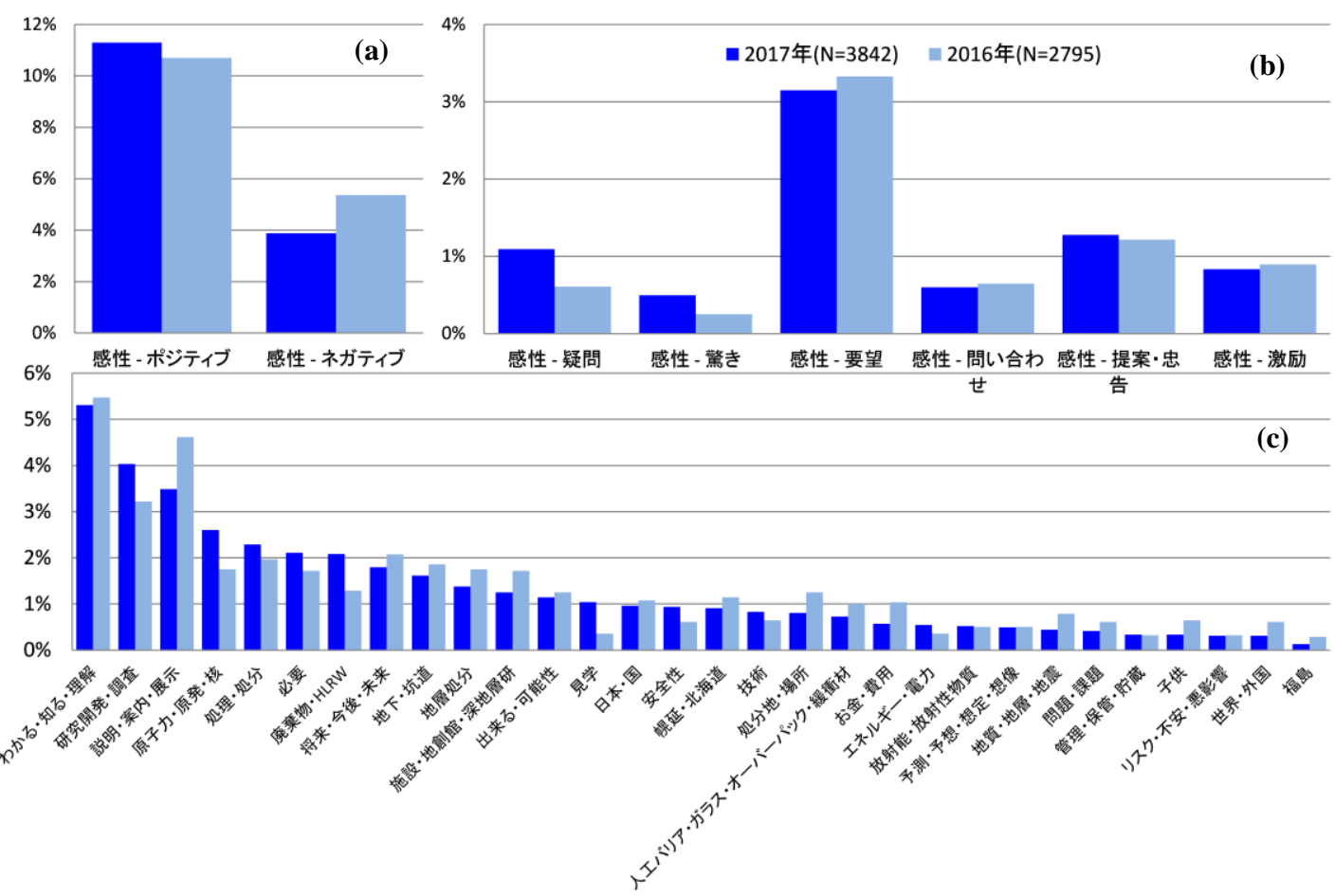

Fig.15 Appearance frequency by description of sentiment ((a) and (b)) and term frequency (c) in 2016 and 2017

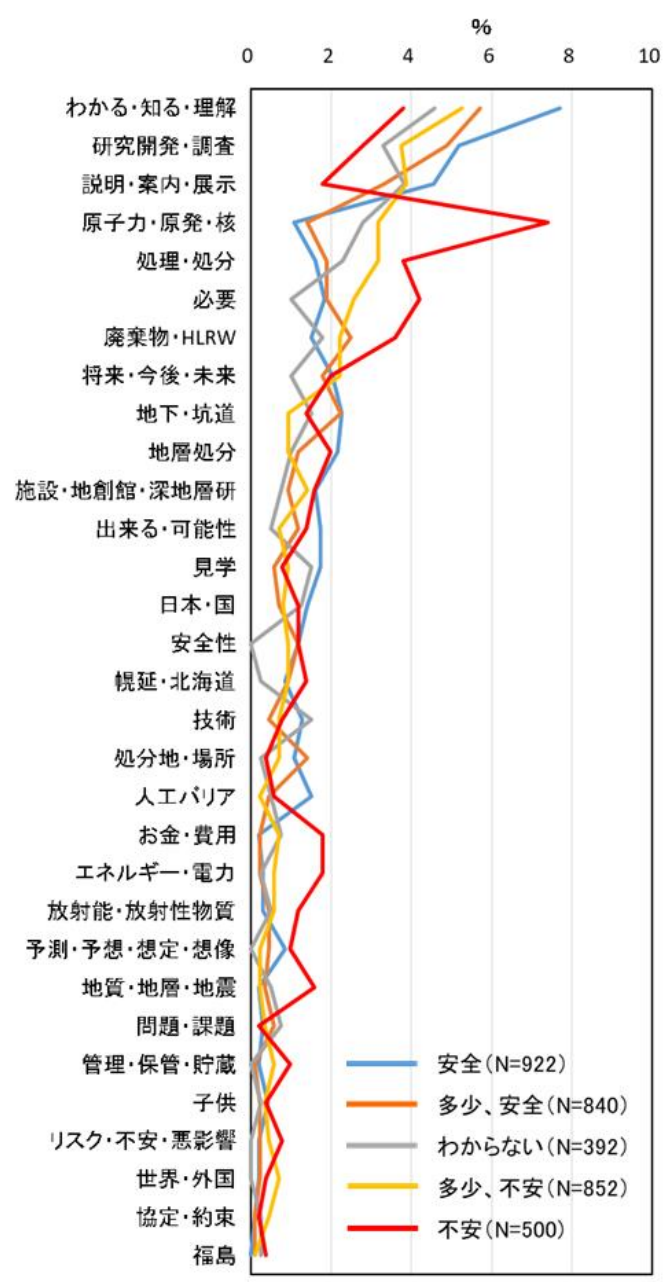

Fig.16(a) Term frequency by the recognition of safety of geological disposal in 2017

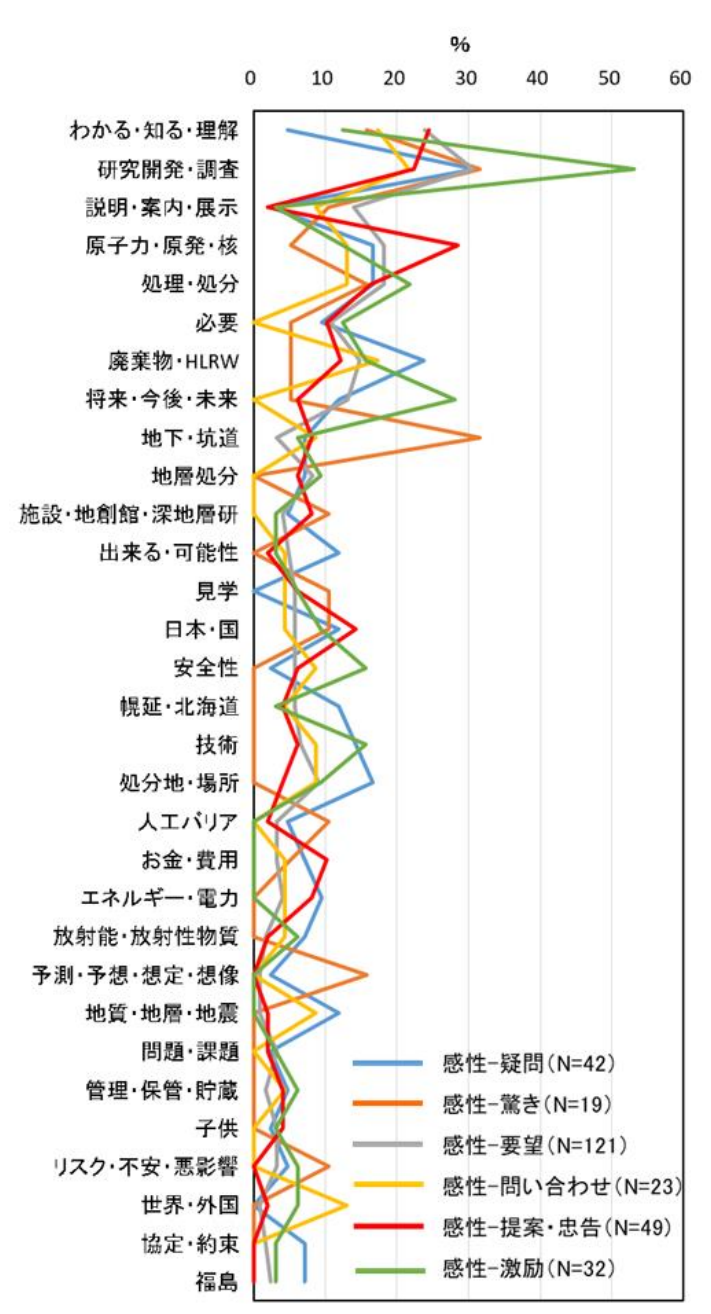

Fig.16(b) Term frequency by the description of sentiment in 2017 


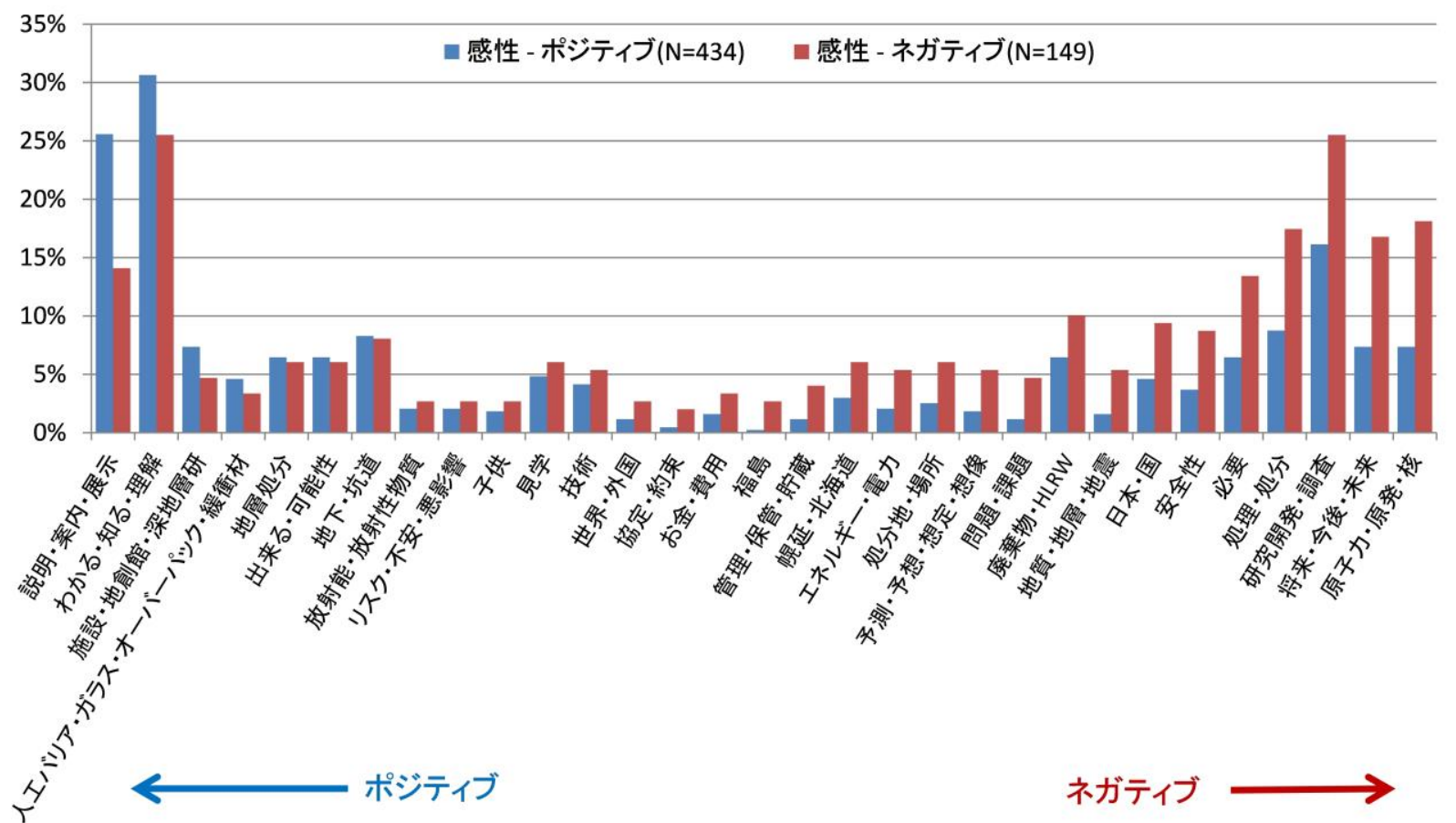

Fig.17 Term frequency by positive and negative description in 2017

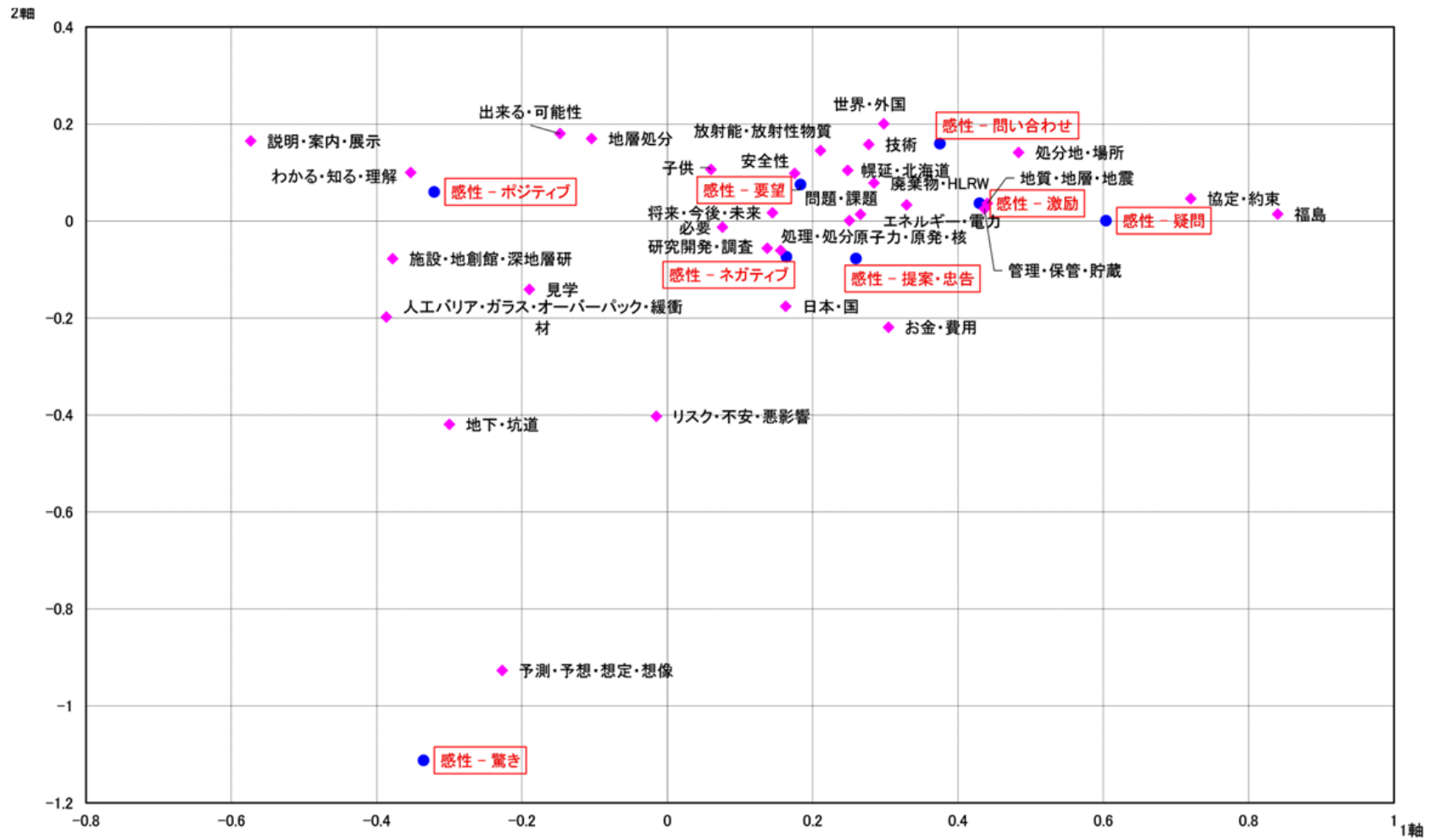

Fig.18 Results of correspondent analysis in terms of appearance terms and description of sentiment in 2017 
がうかがえる（Fig.18）。

\section{4 考察と今後の課題}

回答者の属性のうち, 性別および年齢は 2013 年度から 5 年間大きな変化はない。一方で，居住地については，多い 順に「北海道内」, 「北海道外」, 「幌延町」であり, この傾 向について 5 年間変化はないが，2016 年度以降，「北海道 外」の居住地の回答者の割合が増加している．また，北海 道外の居住者の回答者において, 2016 年度以降, 地層処分 が「適している」との回答が増加，地層処分が「安全」と の回答が増加し,「不安」との回答は減少傾向を示している. これらから，2016 年度以降の居住地の属性の変化（北海道 外の回答者の増加）により, 全体として, 2016 年度以降, 地層処分が「適している」との回答が増加，地層処分が「安 全」との回答が増加し，「不安」との回答は減少傾向を示し たと推察される.

一方，当施設をどのように知ったかについて, 2016, 2017 年度で北海道外の居住者で大きな割合をしめる「その他」 という回答をした人をより詳しく内訳をみると，北海道外 は「業務・学業・関係者」の回答者の割合が高い傾向を示 し, かつ 2016 年度以降その割合は増加している. 今回の調 査では，その他を自由記載で記入していただき，それらの 記載から区分分けしていること，「業務・学業・関係者」の 回答者が，全回答者に対する割合は小さいことから明確な ことは言えないが, このような回答者の属性の変化は, 2015 年度の特定放射性廃棄物の最終処分に関する基本計画の改 定以降，国が前面にたって進めた科学的特性マップの公表

（2017 年 7 月）に向けた国民のみなさまの理解に向けた取 り組みにより，全国から，それらに興味がある見学者が増 加したことによるものと推察される.

HLW 地層処分の安全性に対し「不安」，「多少，不安」， あるいは「わからない」回答した人が選んだ不安内容は， おおむね，順に，「長期間（数万年）の管理」，「相定外のこ とが起こる可能性」,「放射能が外部に漏れてくる可能性」, 「長期間（数万年）減らない放射能」，「日本には適地がな い, となっており，とくに，「長期間（数万年）の管理」, 「想定外のことが起こる可能性」といった，地層処分の長 期の安全性に大きな不安を抱いていることを示している. それと呼応し，「地款変動（地震，火山等）」と「数万年先 の予測」が地層処分の技術的課題として大きく取り上げら れており，今後のリスク・コミュニケーションとして，地 層処分の長期の安全性をどのように示していくのかが課題 となることを示唆している，一方で，「地殼変動（地震，火 山等)」は最も高い技術的課題としてあげられているものの, 2016 年度以降, 各年度の割合は減少傾向にある。これを居 住地別にみると, 2016 年度に幌延町では大きな割合を占め ているものの，北海道内，北海道外ともに，「地款変動（地 震，火山等）」を技術的課題としてあげる割合は減少傾向を 示寸.これらについては，地層処分に関して興味があり， 2015 年度の特定放射性廃棄物の最終処分に関する基本方 針の改定以降，国が前面にたって進めてきた科学的特性マ ップの公表に向けた国民のみなさまの理解に向けた取り組
みの中で，火山や活断層など地殼変動により地層処分施設 に大きな影響を与える要因は除外した場所が選定されると の考えを知っている見学者が多くなったことによる可能性 もあげられるが，その要因については不明であり，今後も モニタリングしていくことが必要である。

また，「地層処分の安全性」に関し，「不安」，「多少，不 安」，あるいは「わからない」と回答した見学者を対象に， 見学後の感想 (理解度) ごとの地層処分の安全性について の不安内容を分析すると，「長期間（数万年）の管理」およ び「想定外のことが起こる可能性」に関しては，理解度が 高い見学者の方が，理解度の低い見学者よりも高い傾向を 示す．さらに，地下研究施設の見学の有無ごとに「地層処 分の安全性」についての不安内容を分析すると,「長期間(数 万年）の管理」および「想定外のことが起こる可能性」に 関しては，地下研究施設の見学の有無に関係なく，高い傾 向を示す。この傾向は，属性や「地層処分の適切さ」およ び「地層処分の安全性」の傾向が変化する 2015 年度以前と 2016 年度以降ともに，同様の傾向を示している．これらの 結果は，理解度が高まると，あるいは地下研究施設を見学 しても，長期の地層処分の安全性については，逆により不 安なこととして浮き彫りになる可能性を示唆しており，今 後の地層処分のリスク・コミュニケーションの課題の 1 つ としてあげられる。

さらに，意見の自由記載の分析結果によると，「原子力・ 原発・核」,「廃棄物・HLW」,「将来・今後・未来」などは, 「要望」,「提案・忠告」あるいは「ネガティブ」表現と関 連する傾向を示すなど，原子力発電やエネルギー問題など に対する要望，忠告といった意見も多くだされており，地 層処分の夕ならず，その前提条件となる上記の内容に関し ても，どのようにリスク・コミュニケーションを行ってい くことが必要なのかについても今後の課題としてあげられ る.

HLW 地層処分の認識のうち，地層処分計画の認知度は, 見学前に知っていたかどうかを質問している．原子力発電 環境整備機構（NUMO）が実施した調查[16]の中の同様な 質問（あなたは「高レベル放射性廃棄物の処分」という問 題についてどの程度ご存知ですか）の回答結果では，2015 年で「知っている」および「聞いたことがある」が $82.6 \%$ ， 2016 年で $84.9 \%$ を示している. 一方で，本調査では，2015 年度で「知っていた」および「何となく（少し）知ってい た」が $86.2 \% ， 2016$ 年度で $85.6 \%$ ある。質問・回答内容 が異なるため直接的には比較できないが，大きな違いは認 められない.「処分の必要性」については，NUMO 調査で は，「あなたは「高レベル放射性廃棄物の処分」は必要だと 思いますか」と質問されており，その結果は，2015 年で「必 要だと思う」および「どちらかといえば必要だと思う」が $78.9 \% ， 2016$ 年で $72.9 \%$ を示す．本調査（見学後の認知） では，2015 年度で「必要」および「多少，必要」が $83.4 \%$, 2016 年度で $85.1 \%$ を示している. 直接的には比較できない が見学後の本調査の方がよりポジティブな評価となってい る.さらに, NUMO 調査では「地層処分の信頼性」として 「地層処分は最も信頼できる処分方法であると思います か」という質問を行っており，その結果は2015 年で「そう 
思う」および「どちらかといえばそう思うが $23.3 \%, 2016$ 年で $22.0 \%$ となっている. 本調査では「地層処分の適切さ」 として質問しており，あくまでも参考にはなるが，2015 年 度で「適している」が $40.5 \%, 2016$ 年度で $46.8 \%$ とかなり ポジティブな評価となっている.さらに，「地層処分の安全 性」は, 2015 年度で「安全」および「多少, 安全」が 40.6\%, 2016 年度で $48.5 \%$ となっている. 以上のように, 質問・回 答項目が異なること, 地層処分に興味がある人が見学に来 ていると推測されること, 当該施設の見学後にアンケート 調査を実施しており，回答者が本施設に肯定的な回答をす るといったバイアスがかかっている可能性があることなど から，限定的なことは言えないが，見学後の調查では，地 層処分に関しよりポジティブな評価になっていることがう かがえる.また,「処分の必要性」,「地層処分の適切さ」お よび「地層処分の安全性」ともに, 地下研究施設を見学し た回答者の方が，見学していない回答者よりポジティブな 評価をしている.

さらに, 出現する語彙を類似する概念ごとに集約すると, 「わかる・知る・理解」, 「説明・案内・展示」は, ポジテ イブな表現の記述に特徵的である。また，感性表現と出現 語彙との関連を検討すると,「ポジティブ」の近くには「説 明・案内・展示」, 「施設・地創館・深地層研」, 「わかる・ 知る・理解」等が布置され, 施設や地下・坑道での説明・ 案内・展示が肯定的に評価されたこと,「地下坑道」は「ポ ジティブ」と「驚き」の中間方向にあり, 地下坑道につい て，その存在についてポジティブに驚きを表現しているの がうかがえる. 加えて, 地下研究施設の見学後の感想（理 解度）についても, 「幌延深地層研究センターで行っている 調査・研究内容」,「地層処分」,「高レベル放射性廃棄物」, 「実物大の人工バリア」,「実物大の人工バリアを使った試 験」ともに, 地下研究施設の見学した回答者の方が, 理解 度が高い。

今回のアンケート調查は, 施設見学の前後ではなく, 見 学実施後のみの実施のため, ゆめ地創館および地下研究施 設の見学の効果を定量的に評価することは難しい. また, 地下研究施設の見学は事前に申し込みが必要なため, 地下 研究施設の見学者の方が, 見学前からよりポジティブな評 価をしている可能性もあり, 確定的なことは言及できない が，上記のことなどから, 地下研究施設の見学が, 見学者 にとって貴重な経験になっている可能性が高いと推測され る. 一方で，地下研究施設の見学に事前予約が必要である ことを認識せずに来館し，失望するケースも散見されるた め, 今後, 事前予約をせずに来館された見学者の方に, VR などで地下空間の模擬体感が可能なような見学コースを検 討していくことが必要と考える.

\section{5 まとめ}

幌延深地層研究センターでは, 国民のみなさまの地層処 分技術に関する研究開発および地層処分の理解を深めるこ とを目的に, ゆめ地創館および地下研究施設を活用してリ スク・コミュニケーションを実施してきた．施設の見学後 に実施しているアンケート調査の結果（2013～2017 年度）
を分析した結果は, リスク・コミュニケーションにより, 理解度が深まることにより, 長期の安全性についてはより 不安な要素としてクローズアップされていることを示唆し ていた.また, 地下研究施設を見学している回答者の方が, 見学していない回答者と比較して, 地層処分の必要性, 適 切性, 安全性をポジティブに評価していることなどから, 本施設の見学が，地層処分の理解にとって貴重な体験にな っていると示唆された.

今後は，これらを踏まえてリスク・コミュニケーション のあり方を改善していくとともに，アンケート調査につい ても, 国民のみなさまの理解の状況や施設見学の効果をよ り定量的に評価することが可能なよう, 改良を加えていく ことが必要である.

\section{謝辞}

ゆめ地創館および地下研究施設の見学対応を行っている 日本原子力研究開発機構幌延深地層研究センターの方々, 見学対応およびアンケート調査のデータ整備を行っている 株式会社ペスコの皆様方, アンケート調査にご協力いただ いた見学者の方々にお礼を申し上げる.

\section{参考文献}

[1] 原子力委員会: 原子力の研究, 開発及び利用に関する 長期計画. 平成6年6月24日 (1994).

[2] 特定放射性廃棄物の最終処分に関寸る基本方針: 平 成27年5月22日閣議決定 (2015).

[3] 太田久仁雄, 阿部寛信, 山口雄大, 國丸貴紀, 石井英 一, 操上広志, 戸村豪治, 柴野一則, 濱克宏, 松井裕 哉, 新里忠史, 高橋一晴, 丹生屋純夫, 大原英史, 浅 森浩一, 森岡宏之, 舟木泰智, 茂田直孝, 福島龍朗: 幌 延深地層研究計画における地上からの調查研究段階

（第 1 段階）研究成果報告書 分冊「深地層の科学的 研究」. JAEA-Research 2007-044 (2007).

[4] 佐藤稔紀, 笹本広, 石井英一, 松岡稔幸, 早野明, 宮 川和也, 藤田朝雄, 棚井憲治, 中山雅, 武田匡樹, 横 田秀晴, 青柳和平, 大野宏和, 茂田直孝, 花室孝広, 伊 藤洋昭: 幌延深地層研究計画における坑道掘削（地下 施設建設）時の調查研究段階（第 2 段階: 深度 $350 \mathrm{~m}$ まで）研究成果報告書. JAEA-Research 2016-025 (2017).

[5] 花室孝広: 幌延深地層研究計画 平成 28 年度調查研 究成果報告. JAEA-Review 2017-025 (2018).

[6] 原子力委員会: 原子力の研究, 開発及び利用に関寸 る長期計画. 平成12年11月24日 (2000).

[7] 日本原子力研究開発機構幌延深地層研究センター: 施設の見学について.

https://www.jaea.go.jp/04/horonobe/visits/index.html (last visited at 21 December 2018).

[8] 日本原子力研究開発機構幌延深地層研究センター: ゆめ地創館.

https://www.jaea.go.jp/04/horonobe/yumechisoukan/index .html (last visited at 25 April 2019). 
[9] 原子力環境整備促進・資金管理センター：地層処分実 規模試験施設.

https://fullscaledemo.rwmc.or.jp/ (last visited at 25 April 2019).

[10] 阿部真也, 片田偉奈雄, 星野雅人, 徳永博昭, 堀越秀 彦: 幌延深地層研究センターゆめ地創館を活用した リスク・コミュニケーションについて. JAEA-Review 2014-034 (2014).

[11] 藤原利如, 片田偉奈雄, 星野雅人, 徳永博昭, 堀越秀 彦: 幌延深地層研究センターゆめ地創館を活用した リスク・コミュニケーションについて（2014 年度）。 JAEA-Review 2015-035 (2016).

[12] 藤原利如, 星野雅人, 徳永博昭, 堀越秀彦: 幌延深地 層研究センターゆめ地創館を活用したリスク・コミュ ニケーションについて（2015 年度）.JAEA-Review 2017-008 (2017).

[13] 野上利信, 星野雅人, 徳永博昭, 堀越秀彦, 川畑一樹: 幌延深地層研究センターゆめ地創館を活用したリス ク・コミュニケーションについて（2016 年度）。 JAEA-Review 2018-003 (2018).

[14] 樋口耕一: 社会調査のための計量テキスト分析 内 容分析の継承と発展を目指して, ナカニシヤ出版, 京都, pp.237 (2014).

[15] 菅民郎: すべてがわかるアンケートデータの分析,.現 代数学社, 京都, pp.140 (1988).

[16] 原子力発電環境整備機構：第28回総合資源エネルギ 一調査会, 電力・ガス事業分科会, 放射性廃棄物口 ーキンググループ, 資料 $2, \mathrm{NUMO}$ の対話活動の取り 組み. 平成28年9月1日, pp.11-12 (2016). 